\title{
Potential spread of forest soil-borne fungi through earthworm consumption and casting
}

\author{
Lucio Montecchio $^{(1)}$, Linda Scattolin ${ }^{(1)}$, Andrea Squartini ${ }^{(2)}$, Kevin \\ Richard Butt ${ }^{(3)}$
}

To test if forest soil-borne fungi concerned with plant health can be selectively dispersed by earthworms, 10 fungal species isolated from 5 forests were presented at 2 concentrations to 3 ecologically distinct earthworm species in laboratory trials. Between 5 and 13 days after introduction, casts were collected (where possible) from each earthworm species fed with a different fungus. These casts were analysed using molecular methods for the presence of the given fungus and its vitality verified through traditional plating techniques. The research confirmed that earthworms have an important role in dispersal of soil fungi in forests, and that such activity can depend on the taxonomical position of the fungus, ecological category of the earthworm species involved and the fungal concentration. In certain instances there is a suggestion that some fungi may be toxic to some earthworms at the given concentrations, which equated to those within and outside of the rhizosphere.

Keywords: Earthworms, Soil-borne Fungi, Fungal Inoculum, Ecology, Dispersal

\section{Introduction}

Since the late 1940 s, there has been a growing interest in soil mycology and soilborne fungal diseases of plants, motivating studies on soil fungi and their ecology (Subramanian 1982, 1986, Carroll \& Wicklow 1992). Such fungi are involved in many plant-soil relationships, including water and nutrient uptake and cycling, plant disease expression or suppression. From a functiona standpoint, such fungi can be grouped according to energy derivation: (i) decomposers (saprotrophic), utilizing dead organic material, sometimes acting antagonistically with others; (ii) mutualists (mycorrhizal), colonizing plant roots, supplying soil nutrients and protection against root parasites in exchange for sugars and possibly other components; (iii) parasites, reducing the growth of plant structures or causing diseases by acting as pathogens.

Relationships among soil-borne fungal species involved in forest plant fitness are complex, in that expansion and spread of one population versus another linked and asso- ciated with other variables (e.g., plant susceptibility, soil $\mathrm{pH}$, temperature, humidity) may lead to changes in plant health. In line with well-known biocontrol strategies (Butt et al. 2001), a parasitic species can seldom express its full pathogenicity against a plant when sufficient mutualistic and/or antagonistic species are present outside of, or within, the rhizosphere (Tousson et al. 1970, Laflamme 2010). The rhizosphere represents a peculiar ecological niche: a common physiological stress on a healthy plant (e.g., an unusual drought period) can easily be reflected in different root exudates, such as sugars and other components, which are important signals of the plant vigor to rhizosphere inhabitants. In this way, a multifaceted dynamic of microbiological interactions, which may awaken their resting stages or chemotactically attract their mobile propagating organs, could lead to establishment of root diseases (e.g., by Phytophthora, Armillaria, Fusarium, Nectria, Verticillium species), the most dangerous in forestry (Manion 1981). In an established forest soil, decomposer fungi $\square$ (1) TeSAF Department, University of Padova, v.le dell'Università 16, I-35020 Legnaro (PD, Italy); (2) DAFNAE Department, University of Padova, v.le dell'Università 16, I-35020 Legnaro (PD, Italy); (3) School of Built and Natural Environment, University of Central Lancashire, Preston PR1 2HE (United Kingdom)

@ Linda Scattolin (linda.scattolin@unipd.it)

Received: Dec 26, 2013 - Accepted: May 24, 2014

Citation: Montecchio L, Scattolin L, Squartini A, Butt KR, 2015. Potential spread of forest soil-borne fungi through earthworm consumption and casting. iForest 8: 295-301 [online 2014-08-26] URL: http://www.sisef.it/iforest/contents/?id=ifor1217-008

Communicated by: Alberto Santini (sometimes with an antagonistic behavior against other microorganisms, including parasites, such as Trichoderma) are commonly present both within and outside of the rhizosphere. By contrast, mutualistic fungi, usually in the rhizosphere (e.g., Laccaria, Pisolithus, Suillus, Xerocomus), can produce toxic metabolites, inhibiting infection by parasitic fungi or physically masking root tips (Smith \& Read 2008). Therefore, the higher is fungal abundance, dispersal rate and positive synergistic effects useful to plants (by decomposers and mutualists), the lower the probability of root disease is likely to be.

Soil fungi represent a large biomass in the soil (Ingham et al. 1989), providing a rich and abundant resource for fungivorous soil invertebrates (Hågvar \& Kjøndal 1981, Takeda \& Ichimura 1983, Visser 1985). Among the latter, earthworms have an active role in soil ecology, altering soil structure, water movement, nutrient dynamics, and plant growth (Lavelle et al. 1997). However, different earthworm species inhabit different parts of the soil, have distinct feeding strategies and can be separated into three major ecological groups (Bouché 1977). These are based primarily on feeding and burrowing habits: (i) epigeic species, living within or close to surface plant litter; (ii) endogeic species, moving and living in the upper soil strata and feeding primarily on soil and associated organic matter; (iii) anecic species, feeding on organic matter and inhabiting semi-permanent burrow systems that may extend vertically down several meters into the soil.

Therefore, earthworms and soil fungi are closely intertwined by direct and indirect grazing, altering spore viability during passage through the gut of the earthworm, and altering the dispersal patterns of fungal propagules by transport (Curry 1998, Dighton 2003). Edwards (1988) demonstrated that earthworms may be capable of selectively digesting some fungal species. However, little is known on the spread of fungi in relation to fungal species and their involvement in forest plant health.

The aim of the current research was to determine whether 10 forest soil-borne fungal species (decomposers, mutualists and parasites), could be dispersed through the earthworms' casts by selected forest dwelling earthworms. To simulate what occurs within and outside of the rhizosphere, where direct plant-soil system interactions take place, the fungal species were offered to earthworms at two different concentrations.

\section{Material and Methods}

\section{Fungal selection and isolation}

Ten soil-borne fungal species belonging to 3 phyla collected from 5 forests located in 
Tab. 1 - Major forest features from sites where experimental fungal species were isolated.

\begin{tabular}{|c|c|c|c|}
\hline Site & $\begin{array}{l}\text { Forest type, elevation } \\
\text { (m a.s.l.), coordinates }\end{array}$ & $\begin{array}{l}\text { Dominant tree } \\
\text { species }\end{array}$ & $\begin{array}{l}\text { Additional tree } \\
\text { species }\end{array}$ \\
\hline 1 & $\begin{array}{l}\text { Pure coniferous }(1572 \mathrm{~m}) \\
46^{\circ} 23^{\prime} \mathrm{N} / 12^{\circ} 10^{\prime} \mathrm{E}\end{array}$ & $\begin{array}{l}\text { European larch } \\
\text { Larix decidua Mill. }\end{array}$ & Picea abies (L.) Karst. \\
\hline 2 & $\begin{array}{l}\text { Mixed forest }(1117 \mathrm{~m}) \\
45^{\circ} 53^{\prime} \mathrm{N} / 11^{\circ} 28^{\prime} \mathrm{E}\end{array}$ & $\begin{array}{l}\text { Norway spruce } \\
\text { Picea abies (L.) Karst. }\end{array}$ & $\begin{array}{l}\text { Abies alba Mill., } \\
\text { Fagus sylvatica L. }\end{array}$ \\
\hline 3 & $\begin{array}{l}\text { Broadleaved }(54 \mathrm{~m}) \\
45^{\circ} 38^{\prime} \mathrm{N} / 11^{\circ} 31^{\prime} \mathrm{E}\end{array}$ & $\begin{array}{l}\text { European alder } \\
\text { Alnus glutinosa } \mathrm{L} \text {. }\end{array}$ & $\begin{array}{l}\text { Acer pseudoplatanus L., } \\
\text { Fraxinus excelsior L. }\end{array}$ \\
\hline 4 & $\begin{array}{l}\text { Broadleaved (9 m) } \\
45^{\circ} 49^{\prime} \mathrm{N} / 12^{\circ} 31^{\prime} \mathrm{E}\end{array}$ & $\begin{array}{l}\text { Common oak } \\
\text { Quercus robur L. }\end{array}$ & $\begin{array}{l}\text { Carpinus betulus L. Fraxinus } \\
\text { oxycarpa Bieb., Ulmus minor } \\
\text { Mill., Prunus avium L. }\end{array}$ \\
\hline 5 & $\begin{array}{l}\text { Broadleaved (2 m) } \\
45^{\circ} 07^{\prime} \mathrm{N} / 12^{\circ} 15^{\prime} \mathrm{E}\end{array}$ & $\begin{array}{l}\text { Holm oak } \\
\text { Quercus ilex L. }\end{array}$ & $\begin{array}{l}\text { Ostrya carpinifolia Scop., } \\
\text { Fraxinus ornus L. }\end{array}$ \\
\hline
\end{tabular}

the Veneto region (north-eastern Italy - Tab. 1) were selected according to the parasitic, mutualistic or hyperparasitic groups with forest plants. Soils from these and similar forests are known to support earthworm communities which include the 3 species selected for this trial (Zanella et al. 2001, Edwards \& Bohlen 1996).

The Oomycete Phytophthora cactorum (Lebert \& Cohn) J. Schröt. (plant parasite), the Ascomycete Neonectria radicicola (Gerlach \& L. Nilsson) Mantiri \& Samuels [anam. Cylindrocarpon destructans (Zinssm.) Scholten], Fusarium reticulatum Mont., Verticillium dahliae Kleb. (plant parasites) and Trichoderma harzianum Rifai (fungal hyperparasite), and the Basidiomycote $A r$ millaria ostoyae (Romagn.) Herink. (plant parasite), Laccaria laccata (Scop. ex Fr.)
Bk. \& Br., Pisolithus arhizus (Scop.) Rauschert, Suillus grevillei (Klotzsch) Singer and Xerocomus chrysenteron (Bull.) Quél. (plant mutualists) were isolated and purified in 2008 (Tab. 2).

$P$. cactorum, $N$. radicicola, $F$. reticulatum and $V$. dahliae were isolated from fragments (1-2 mm long) of infected rootlets surfacesterilized with $0.5 \%$ sodium hypochlorite, thoroughly rinsed with sterile water and plated on PDA (Montecchio 2005). T. harzianum was isolated from $4 \mathrm{~cm}$ deep soil cores using 10-fold serial dilutions of soil on Trichoderma medium E (TME - Carrillo et al. 2004). A. ostoyae, L. laccata, P. arhizus, $S$. grevillei and X.chrysenteron pure cultures were obtained from internal tissues of young, undamaged sporocarps; A. ostoyae was plated on Potato dextrose agar (PDA), while those remaining were plated on MMNA ("modified Melin-Norkrans liquid medium" with $1.5 \%$ agar; Erwin et al. 1983 - Tab. 2). $P$. cactorum, $N$. radicicola, $F$. reticulatum, $T$. harzianum and $V$. dahliae were morphologically identified (Rifai 1969, Nelson et al. 1983, Kim et al. 2001, Samuels et al. 2006). A. ostoyae, L. laccata, P. arhizus, S. grevillei and $\mathrm{X}$. chrysenteron sporocarps were identified according to Nilson \& Persson (1978) and Bérubé \& Dessureault (1988).

Also for subsequent investigations and comparisons (see below), the identity of the fungal species was confirmed by DNA extraction, ITS PCR and sequencing. In detail, $P$. cactorum was identified according to $\mathrm{Ca}$ usin et al. (2005), P. arhizus upon Henrion et al. (1994), and all the remaining fungi according to Morris et al. (2008). The sequences obtained were compared to those available in the NCBI (http://www.ncbi.nih.gov) and UNITE (http://unite.ut.ee) databases.

\section{Fungal inoculum production}

Each purified fungal strain was cultured in liquid medium (PDB or MMN - Tab. 2). For every strain a 1 liter flask containing $500 \mathrm{ml}$ of medium was inoculated, with a blended 10 -ml slurry of one $6 \mathrm{~cm}$ diam pure colony, previously grown on its agarized medium and maintained in an orbital shaker (50 r.p.m., $20 \pm 1{ }^{\circ} \mathrm{C}$ in the dark) up to the concentration of at least $10^{3}$ propagules (spores, mycelial fragments) $\mathrm{cm}^{-3}$, checked every 72 $\mathrm{h}$ by a Thoma hematocytometer. The mycelium from each flask was then blended for $10 \mathrm{~s}$, diluted at $10^{2}$ propagules in sterile wa-

Tab. 2 - Species (strain and isolation site according to Tab. 1), main behaviour, substrate of isolation and growing media. (PDA): Potato Dextrose Agar (BD, Becton, Dickinson and Company, NJ, USA); (PDB): Potato Dextrose Broth (BD, NJ, USA); (MMN): modified MelinNorkrans liquid medium; (MMNA): MMN added with $1.5 \%$ agar; (TME): Trichoderma medium E.

\begin{tabular}{llll}
\hline $\begin{array}{l}\text { Species strain } \\
\text { code (site code) }\end{array}$ & Main behaviour & $\begin{array}{l}\text { Substrate } \\
\text { of isolation }\end{array}$ & $\begin{array}{l}\text { Isolation and purification } \\
\text { media / liquid culture media }\end{array}$ \\
\hline $\begin{array}{l}\text { A. ostoyae } \\
\text { (AM-13 2) }\end{array}$ & parasitic (root rot - Prospero et al. 2004) & Sporocarp below Norway spruce & PDA / PDB \\
\hline $\begin{array}{l}\text { N. radicicola } \\
\text { (CD-2 3) }\end{array}$ & parasitic (root rot, wilt - Montecchio \& Causin 1995) & Rootlets from European alder & PDA / PDB \\
\hline $\begin{array}{l}\text { F.reticulatum } \\
\text { (FR-1 4) }\end{array}$ & $\begin{array}{l}\text { parasitic (root rot, wilt - Montecchio \& Mutto } \\
\text { Accordi 2007) }\end{array}$ & Rootlets from Common oak & PDA / PDB \\
\hline $\begin{array}{l}\text { P. cactorum } \\
\text { (PC-6 5) }\end{array}$ & parasitic (root rot, wilt - Vettraino et al. 2002) & Rootlets from Holm oak & PDA / PDB \\
\hline $\begin{array}{l}\text { V. dahliae } \\
\text { (VD-4 4) }\end{array}$ & parasitic (root rot, wilt - Ndubizu 2008) & Rootlets from Prunus avium & PDA / PDB \\
\hline $\begin{array}{l}\text { L. laccata } \\
\text { (LL-4 2) }\end{array}$ & mutualistic (ectomycorrhizal - Di Marino et al. & Sporocarp below Norway spruce & MMNA / MMN \\
\hline $\begin{array}{l}P . \text { arhizus } \\
\text { (PT-7 4) }\end{array}$ & mutualistic (ectomycorrhizal - Dixon et al. 1984) & Sporocarp below Common oak & MMN / MMN \\
\hline $\begin{array}{l}\text { S. grevillei } \\
\text { (SE-1 1) }\end{array}$ & mutualistic (ectomycorrhizal - Kottke et al. 1987) & Sporocarp below European larch & MMN / MMN \\
\hline $\begin{array}{l}\text { X.chrysenteron } \\
\text { (XD-3 5) }\end{array}$ & mutualistic (ectomycorrhizal - Diedhiou et al. 2010) & Sporocarp below Holm oak & MMN / MMN \\
\hline $\begin{array}{l}\text { T. harzianum } \\
\text { (TH-24 3) }\end{array}$ & $\begin{array}{l}\text { hyperparasite (root parasites' antagonist - Papavizas } \\
\text { \& Lumsden 1982) }\end{array}$ & Organic soil layer & TME / PDB \\
\hline
\end{tabular}


ter and used to inoculate six 2-liter sterile containers for each fungal species, containing $500 \mathrm{ml}$ of sterile Kettering loam soil mixture (GSB loams, Kettering, Northants, $\mathrm{UK} ; \mathrm{pH} 7.7,5.5 \%$ organic matter), moistened to $85-90 \%$ RU with sterile liquid medium, previously stored for 2 days at room temperature to allow the stabilization of the medium.

Inoculated soils were then cultured at $20 \pm$ $1{ }^{\circ} \mathrm{C}$ in the dark. Every $72 \mathrm{~h}$, the fungal viability was verified by plating fragments onto agarized medium (PDA, MMNA, TME), observing the mycelial growth. Furthermore, the fungal concentration was assessed by means of a Thoma's hematocytometer on a mixture of five $1 \mathrm{~cm}^{3}$ sub-samples randomly collected from different portions of the container content

For every strain, the incubation was considered complete when 3 containers reached the concentration of $1-3 \cdot 10^{3}$ propagules $\mathrm{cm}^{-3}$ and the remaining three $1-3 \cdot 10^{5}$ propagules $\mathrm{cc}^{-1}$, allowing the set up of 20 treatments (10 fungi $\times 2$ concentrations) of 3 replicates each. The two fungal concentrations were chosen as likely average values in forest soils outside and inside the rhizosphere, according both to preliminary investigation by the authors in forest sites 1, 2 and 4 (Tab. 1), and to the scientific literature (Foster 1985, Smith 1985, Pečiulyte \& Dirginčiute-Volodkiene 2009, Saravanakumar \& Kaviyarasan 2010).

\section{Earthworm maintenance and cast collection}

After incubation, whose length varied depending on the planned concentrations of fungal species (7-35 days), the content of each container was transferred to three 750 $\mathrm{ml}$ sterile plastic vessels suitable for earthworm culture (Lowe \& Butt 2005). In each vessel a single, healthy adult of Lumbricus terrestris L., L. rubellus (Hoffmeister) or Aporrectodea caliginosa (Savigny), laboratory-bred and randomly obtained from groups producing casts lacking fungal propagules (plating casts in the 3 agarized media) was transferred and stored at $15 \pm 1{ }^{\circ} \mathrm{C}$ in the dark for 13 days. These earthworm species were chosen as representatives of the 3 above-mentioned major ecological categories (Bouché 1977).

After 5, 7, 9, 11 and 13 days, each earthworm was removed from the soil, assessed, and classified as: (i) active; (ii) coiled in a resting stage (producing casts or not); or (iii) dead. Each earthworm was rinsed with distilled water, blotted dry (to remove surface soil) and then gently manipulated, such that casts were produced and the latter deposited directly into two sterile tubes: one for plating and the other one for DNA analysis. The earthworm was then returned to the given pot. When casts were not available from ac- tive or coiled earthworms, casts were defined as absent. Collected casts were stored at $5 \pm$ $2{ }^{\circ} \mathrm{C}$ in darkness for no more than 10 days.

\section{Fungal presence and vitality in casts}

Casts from the tube for plating were used to verify the presence of the fungus previously inoculated into the soil by means of the molecular methods reported above. When the fungus was detected in at least one cast among those obtained across the whole collection period, the fungus was classified as present, otherwise it was considered absent.

Casts from the tube for DNA analysis were used to verify the vitality of the fungus present. To this purpose, all casts were singly plated in $9 \mathrm{~cm}$ diam Petri dishes (PDA, MMNA, TME, all treated with streptomycin sulphate $80 \mathrm{mg} \mathrm{l}^{-1}$ after autoclaving, to limit bacterial proliferations) and incubated at $20 \pm 1{ }^{\circ} \mathrm{C}$ in the dark. Growing colonies were inspected every 2 days over a 15-day period using a compound microscope for the morphological features of the inoculated fungal species. All colonies were then isolated, purified and classified on molecular bases as previously reported, comparing the obtained sequences. When the fungal species was confirmed from at least one cast, the fungus was considered as vital; otherwise it was considered as non vital.

\section{Results}

Results showed that earthworm behavior was greatly influenced by the fungal phylum and mycelium's concentration (Tab. 3).

Lumbricus terrestris demonstrated a sharply different behavior when fed with Oomycota and Ascomycota compared with Basidiomycota. For the first group ( $P$. cactorum, $N$. radicicola, $F$. reticulatum and $V$. dahliae, plant parasites and T. harzianum, their hyperparasite) at both fungal concentration and for the whole experiment period, L. terrestris maintained full fungal vitality, producing casts where the fungal species were present and vital. In contrast, when fed with fungi belonging to the Basidiomycota, only the root parasite $A$. ostoyae caused no adverse effects at both concentrations, even if detected in casts, also if not vital, only at the lower concentration. By comparison, when fed with all of the mutualistic Basidiomycota (L. laccata, P. arhizus, S. grevillei and X. chrysenteron), stress symptoms appeared, such as inactivity and no cast production after 5-11 days, and the fungi were never detected in casts.

Lumbricus rubellus behaved as L. terrestris for the Ascomycota, at both concentrations, and for $P$. cactorum at the lower concentration, but produced casts with non-vital fungus and died after 9 days when cultured with $P$. cactorum at the higher concentration. Furthermore, when grown with A. osto- yae and $S$. grevillei, stress symptoms did not appear, whilst death was detected from day 5, 9 and 11 (L. laccata, P. arhizus, X. chrysenteron, respectively) in the other treatments. Besides, none of the Basidiomycetes was found living in casts: $A$. ostoyae at both fungal concentrations; L. laccata, $P$. arhizus and $S$. grevillei at the lower concentration were present, but not alive; at higher concentrations the fungi were absent, as for $X$. chrysenteron at both concentrations.

Quite different results arose from A. caliginosa treatments, where stress symptoms never appeared when grown with N. radicicola, F. reticulatum, T. harzianum and $P$. arhizus at the lower concentration. In all other treatments, stress symptoms appeared (resting stages, dead, or no cast production). Regardless of the fungal presence in casts, from the lower concentration trials, $P$. cactorum, all the Ascomycota, S. grevillei and $X$. chrysenteron were present and living, while A. ostoyae, L. laccata and P. arhizus were detected but not vital. In the casts collected at the higher concentration trials, only $F$. reticulatum was living, while all others were not present.

\section{Discussion and conclusions}

The dispersal strategy of forest soil fungi, independent of their relationships with plants, is a key factor from a phytopathological point of view. Soil-borne fungi rarely disperse over great distances (Bruehl 1987) spreading themselves by means of slow hyphal growth towards a nutritional source (Fitter \& Garbaye 1994), but their interactions with a wide range of micro- and macroorganisms (Reddell \& Spain 1991, Jayasinghe \& Parkinson 2009) can assist passive coverage of larger distances and areas. Among these, earthworms probably more than others interact substantially with forest soil, with a feeding behavior influenced mainly by their soil exploration strategies (epigeic, endogeic, anecic). Their ability to select and feed on samples infected by a given fungal species, digesting or depositing as vital within casts is well documented (Piearce 1978, Cooke \& Luxton 1980, Cooke 1983, Moody et al. 1996, Bonkowski et al. 2000), but further information is needed on earthworm involvement in the propagation of fungi involved in forest plant health, with increasing distance from the plant.

The experiment performed confirmed (Moody et al. 1996, Shankar et al. 2002) that different earthworm species can feed on different fungi, with total digestion, or their release with at least partial vitality in casts, with differences in this ability mainly due to the fungal phylum and fungal concentration. Results obtained here were partially comparable with those of Bonkowski et al. (2000), where pathogenic fungi were preferred over Trichoderma, but in our experiment the 
Tab. 3 - Earthworm status at two fungal concentrations (103, 105 propagules $\mathrm{cc}^{-1}$ of soil) and fungus status in casts. Earthworm: $(\bullet)$ : active; $(\diamond)$ : coiled in a resting stage but producing casts; $(-)$ : coiled but not producing casts; $(\dagger)$ : dead. Fungus: $(\bullet)$ : present and vital; $(\dagger)$ : present and non vital; (-): absent.

\begin{tabular}{|c|c|c|c|c|c|c|}
\hline \multirow{2}{*}{$\begin{array}{l}\text { Earthworm } \\
\text { species }\end{array}$} & \multirow{2}{*}{$\begin{array}{l}\text { Fungus } \\
\text { Order }\end{array}$} & \multirow{2}{*}{$\begin{array}{l}\text { Fungus } \\
\text { species }\end{array}$} & \multicolumn{2}{|c|}{ Earthworm status } & \multicolumn{2}{|c|}{ Fungus status } \\
\hline & & & $10^{3}$ & $10^{5}$ & $10^{3}$ & $10^{5}$ \\
\hline \multirow[t]{10}{*}{ L. terrestris } & Oomycota & P. cactorum & $\bullet$ & $\bullet$ & $\bullet$ & $\cdot$ \\
\hline & Ascomycota & N. radicicola & $\cdot$ & $\bullet$ & $\bullet$ & $\cdot$ \\
\hline & & F. reticulatum & $\bullet$ & $\bullet$ & $\bullet$ & $\bullet$ \\
\hline & & T. harzianum & $\cdot$ & $\bullet$ & $\cdot$ & $\cdot$ \\
\hline & & V. dahliae & $\bullet$ & $\bullet$ & $\bullet$ & $\cdot$ \\
\hline & Basidiomycota & A. ostoyae & $\cdot$ & $\bullet$ & $\dagger$ & - \\
\hline & & L. laccata & -(- from day 11$)$ & $\cdot$ & - & - \\
\hline & & P. arhizus & $\bullet$ & $\cdot(\diamond$ from day 5$)$ & - & - \\
\hline & & S. grevillei & $\cdot$ & -(- from day 11$)$ & - & - \\
\hline & & X. chrysenteron & $\cdot$ & •(- from day 7) & - & - \\
\hline \multirow[t]{10}{*}{ L. rubellus } & Oomycota & P. cactorum & $\cdot$ & $\cdot(\dagger$ from day 9$)$ & $\bullet$ & $\dagger$ \\
\hline & Ascomycota & N. radicicola & $\cdot$ & $\bullet$ & $\cdot$ & $\cdot$ \\
\hline & & F. reticulatum & $\cdot$ & $\bullet$ & $\bullet$ & $\cdot$ \\
\hline & & T. harzianum & $\cdot$ & $\cdot$ & $\cdot$ & $\cdot$ \\
\hline & & V. dahliae & $\cdot$ & • & $\cdot$ & $\cdot$ \\
\hline & Basidiomycota & A. ostoyae & $\cdot$ & $\cdot$ & $\dagger$ & $\dagger$ \\
\hline & & L. laccata & $\cdot$ & $\cdot(\dagger$ from day 5$)$ & $\dagger$ & - \\
\hline & & P. arhizus & $\cdot$ & $\cdot(\dagger$ from day 9$)$ & $\dagger$ & - \\
\hline & & S. grevillei & $\cdot$ & • & $\dagger$ & - \\
\hline & & $X$. chrysenteron & $\cdot$ & $\cdot(\dagger$ from day 11$)$ & - & - \\
\hline \multirow[t]{10}{*}{ A. caliginosa } & Oomycota & P. cactorum & $\cdot(-$ from day 13$)$ & $\cdot(\diamond$ from day 5$)$ & $\bullet$ & - \\
\hline & Ascomycota & N. radicicola & • & $\cdot(\dagger$ from day 5$)$ & • & - \\
\hline & & F. reticulatum & $\cdot$ & $\cdot(\dagger$ from day 11$)$ & $\cdot$ & $\cdot$ \\
\hline & & T. harzianum & $\cdot$ & $-(\dagger$ from day 11$)$ & $\cdot$ & - \\
\hline & & V. dahliae & $\bullet(\diamond$ from day 7$)$ & - $(\dagger$ from day 9$)$ & $\bullet$ & - \\
\hline & Basidiomycota & A. ostoyae & $\cdot(\diamond$ from day 11$)$ & - & $\dagger$ & - \\
\hline & & L. laccata & $\cdot(\diamond$ from day 13$)$ & $-(\dagger$ from day 11$)$ & $\dagger$ & - \\
\hline & & P. arhizus & $\cdot$ & $\cdot(\dagger$ from day 9$)$ & $\dagger$ & - \\
\hline & & S. grevillei & $\cdot(\diamond$ from day 13$)$ & - $(\diamond$ from day 9$)$ & $\bullet$ & - \\
\hline & & X. chrysenteron & - $(\diamond$ from day 13$)$ & $\diamond(\dagger$ from day 11$)$ & $\cdot$ & - \\
\hline
\end{tabular}

species used were different. By comparison, when fed with Basidiomycota the earthworms showed a species-specific behavior. Lumbricus terrestris produced casts containing dead hyphae of $A$. ostoyae, typically a root rotter fungus, while no DNA traces of all other Basidiomycota (all ectomycorrhizal) were found in casts. Lumbricus rubellus demonstrated an ability to feed on all of the Basidiomycota given, excluding the mycorrhizal $X$. chrysenteron, but these were never found as vital in casts. A. caliginosa fed on all of the Basidiomycota, producing casts with dead propagules of A. ostoyae, L. laccata and $P$. arhizus, and living propagules of $S$. grevillei and $X$. chrysenteron.

The destiny of ingested microorganisms depends on their adaptation to the intestinal conditions of the earthworm (Dash et al. 1986, Moody et al. 1995, 1996, Buck et al. 2000). Two opposing processes act during digestion. Favorable $\mathrm{pH}$-value, increased nutrient and water supply in the gut increases the microbial population during gut passage (Barois \& Lavelle 1986), whilst intestinal transit and fluids can reduce numbers of species by digestion (Devliegher \& Verstraete 1995). According to these results, our study showed that all earthworms allowed a safe transit of all the non-Basidiomycetes and that the parasitic Basidiomycete A. ostoyae was fed upon and totally digested. Moreover, the remaining Basidiomycetes, all mycorrhizal, ranged from rejection (L. terrestris) to ingestion (A. caliginosa). Moreover, in the latter a total digestion of some mycorrhizal Basidiomycete (L. laccata, P. arhizus) and a lack or incomplete digestion of others $(S$. grevillei and $X$. chrysenteron) was observed.

As earthworms prefer the habitats in which they forage (Reddell \& Spain 1991, Dighton 2003), considering 7 days is enough both to feed and, for $L$. terrestris, to potentially move several meters away from the point of grazing (Mather \& Christensen 1988), we might suppose that all the earthworms tested can spread the given Oomycota and the Ascomycetes (1 antagonist, 4 root parasites). Furthermore, A. caliginosa can act as a vector of 2 mutualistic fungi. Observed stress symptoms of this earthworm species, likely attributable to mycotoxic effects (Smith \& Read 2008), need further investigation.

In contrast with Moody et al. (1995), under our experimental conditions no differences in earthworm preference were observed among Ascomycetes, apart from A. caliginosa that, at the highest concentration, exclusively preferred $F$. reticulatum.

In summary, the non-Basidiomycetes, frequently quickly colonizing the superficial soil layers when present in low concentrations (as typically happens in bulk soil), are easily fed upon and transported alive to other ecologically similar sites by earthworms. This resulted, moreover, independently from the behavior (relationship with plants) of the latter. Increasing the fungal concentration, as usually happens moving from bulk soil to rhizosphere, this ability characterizes mainly epigeic and anecic species (Bonkowski et al. 2000). As the Oomycetes studied were restricted to just one species, such wide considerations can be only speculative, but earthworms may act as with the Ascomycetes. The Basidiomycetes (including the root parasite A. ostoyae and 4 ectomycorrhizal fungi) were not fed upon, or were eaten and totally digested, probably due to their low food quality for earthworms (Bonkowski et al. 2000). Among them, as a general trend, ectomycorrhizal fungi were detected alive in casts only in the pairs A. caliginosa $+S$. grevillei and $X$. chrysenteron: often they were 
not eaten (L. terrestris in all concentrations, L. rubellus and A. caliginosa in the highest concentration), sometimes they were eaten and totally digested. Unfortunately, little is known to explain these results as, unlike endomycorrhizae (Gange 1993), zootrophic dispersal of ectomycorrhizae has been widely documented only with small mammals (Trappe 1988, Kotter \& Farentinos 1984 Reddell \& Spain 1991). Generally, the reported results confirmed that earthworms have an important role in spreading soil fungi in forests, and that such activity can depend on both the ecological grouping of the three species involved, and the fungal concentration, widening the knowledge on the ecologic dynamics related to forest plants' health within the soil. Fast-growing species were preferred to Basidiomycetes, generally refused, with a general food preference irrespective of earthworm ecological group, visible only when associated to the rhizospheric fungal concentrations. This allowed us to suggest that fungi characteristic of early successional stages of decomposition can be used by earthworms as cues to detect fresh and nutrient rich organic resources in soil. In accordance with previous papers (Scheu 1987, Scheu \& Schaefer 1988 Tiunov \& Scheu 2000, Bonkowski et al. 2000 ), considering the ecological role of fungi as part of the plant, decomposer community may provide a deeper insight into the underlying mechanisms, than simply referring to food preferences of earthworms. This hypothesis is supported by the observed food preferences of earthworms: the most preferred fungi of earthworms include many plant tissue parasites which commonly attack either plantlets and adult plants (Phytophthora, Fusarium, Verticillium, Nectria). The selectivity for fungal species differed considerably among earthworm species in our experiment, indicating differential use of fungi as food or food indicators by earthworms Detritivore epigeic and anecic earthworm species, $L$. rubellus and $L$. terrestris, respectively, are important consumers of litter material which is generally densely colonized by fungi. These species have been shown to be more selective in their food choices (Hendriksen 1990), and the distinctive preferences for certain fungal species by the epigeic $L$. rubellus and anecic $L$. terrestris are in accordance with our expectations. In contrast, the geophagous endogeic species A. caliginosa was highly selective (only Fusarium reticulatum at rhizospheric concentration) and consumed less material. Endogeic species consume high amounts of mineral soil (Judas 1992) and rely less on fresh litter resources.

A general trend can be proposed: outside of the rhizosphere or during secondary successions (e.g., after fires), propagules from surviving vegetation can be more readily moved into new areas, being recolonized by plants than could be achieved via physical dispersal alone. Where low fungal concentration is common, non-Basidiomycetes have greater opportunities than other fungi to be spread by earthworms. This could explain the capillary presence of Fusarium and Verticillium infections, also in seedlings, along an ecotonal forest border, probably also passively vectored by earthworms or other soil fauna.

As the effects of any competition in species assembly is difficult to demonstrate (Connor \& Simberloff 1979), a combined use of experimentation and mathematical modeling could be useful. Further investigation and results are needed to analyze the numerous abiotic and biotic variables dynamically interacting in the rhizosphere and having a role in plant diseases epidemiology.

\section{Acknowledgements}

The authors wish to thank Dr. M. Stefenatti and Mr. S. Zanella for their help in fungal isolations and molecular analyses.

\section{References}

Barois I, Lavelle P (1986). Changes in respiration rate and some physicochemical properties of a tropical soil during transit through Pontoscolex corethrurus. Soil Biology and Biochemistry 18 (5): 539-541. - doi: 10.1016/0038-0717(86)9001 2-X

Bérubé JA, Dessureault M (1988). Morphological characterization of Armillaria ostoyae and $\mathrm{Ar}$ millaria sinapina sp. nov. Canadian Journal of Botany 66 (10): 2027-2034. [online] URL: http://www.nrcresearchpress.com/doi/abs/10.113 9/b88-277

Bonkowski M, Griffiths BS, Ritz K (2000). Food preferences of earthworms for soil fungi. Pedobiologia 44: 666-676. - doi: 10.1078/S0031-40 56(04)70080-3

Bouché MB (1977). Strategies lombriciennes [Earthworms strategies]. In: "Soil Organisms as Components of Ecosystems" (Lohm U, Person T eds). Ecological Bulletin 25: 122-132. [in French] [online] URL: http://www.jstor.org/stable/20112572

Bruehl GW (1987). Soilborne plant pathogens. MacMillan Publishing Company, New York, USA, pp. 368. [online] URL: http://www.cabdirect.org/abstracts/19871337460.html

Buck C, Langmaack M, Schrader S (2000). Influence of mulch and soil compaction on earthworm cast properties. Applied Soil Ecology 14 (3): 223-229. - doi: 10.1016/S0929-1393(00)000 54-8

Butt TM, Jackson C, Magan N (2001). Fungi as biocontrol agents: progress, problems and potential. CABI Publications, Wallingford, UK, pp. 18. - doi: 10.1079/9780851993560.0000

Carrillo C, Diaz G, Honrubia M (2004). Improving the production of ectomycorrhizal fungus mycelium in a bioreactor by measuring the ergosterol content. Engineering in Life Sciences 4
(1): 43-45. - doi: 10.1002/elsc.200420003 Carroll GC, Wicklow DT (1992). The fungal community. Its organization and role in the ecosystem. In "Mycology, vol. 9 ( $2^{\text {nd }}$ edn)". Marcel Dekker Inc., New York, USA, pp. 952. [online] URL: http://books.google.com/books?id=ikJfKa z01EEC

Causin R, Scopel C, Grendene A, Montecchio L (2005). An improved method for the detection of Phytophthora cactorum (L.C.) Schröeter in infected plant tissues using SCAR markers. Journal of Plant Pathology 87: 25-35. [online] URL: http://www.jstor.org/stable/41998204

Connor EF, Simberloff D (1979). The assembly of species communities: chance or competition? Ecology 60: 1132-1140. - doi: 10.2307/1936961 Cooke A (1983). The effects of fungi on food selection by Lumbricus terrestris L. In: "Earthworm Ecology - From Darwin to vermiculture" (Satchell JE ed). Chapman \& Hall, London, UK, pp. 365-381.

Cooke A, Luxton M (1980). Effect of microbes on food selection by Lumbricus terrestris. Revue d'Ecologie et de Biologie du Sol 17 : 365-373. [online] URL: http://www.cabdirect.org/abstracts /19811960450.html

Curry JP (1998). Factors affecting earthworm abundance in soil. In: "Earthworm Ecology" (Edwards CA ed). St. Lucie Press, Boca Raton, FL, USA, pp. 37-64.

Dash HK, Beura BN, Dash MC (1986). Gut load, transit time, gut microflora and turnover of soil, plant and fungal material by some tropical earthworms. Pedobiologia 2: 13-20. [online] URL: http://cat.inist.fr/?aModele $=$ afficheN\&cpsidt $=79$ 03666

Devliegher W, Verstraete W (1995). Lumbricus terrestris in a soil core experiment: nutrient-enrichment processes (NEP) and gut associated processes (GAP) and their effect on microbial biomass and microbial activity. Soil Biology and Biochemistry 27 (12): 1573-1580. - doi: 10.1016 /0038-0717(95)00090-2

Di Marino E, Montecchio L, Scattolin L, Abs C, Agerer R (2009). The ectomycorrhizal community structure in European beech forests differing in coppice shoot age and stand features. Journal of Forestry 107 : 250-259. [online] URL: http:// www.ingentaconnect.com/content/saf/jof/2009/0 0000107/00000005/art00009

Diedhiou AG, Dupouey JL, Buée M, Dambrine E, Laüt L, Garbaye J (2010). The functional structure of ectomycorrhizal communities in an oak forest in central France witnesses ancient GalloRoman farming practices. Soil Biology and Biochemistry 42 (5): 860-862. - doi: 10.1016/j.soilbio. 2010.01 .011

Dighton J (2003). Fungi in ecosystem processes. M. Dekker Inc., New York, USA, pp. 424. [online] URL: http://books.google.com/books?id=bJ Kw_BpzUkcC

Dixon RK, Garrett HE, Cox GS, Marx DH Sander IL (1984). Inoculation of three Quercus species with eleven isolates of ectomycorrhizal fungi. I. Inoculation success and seedling growth relationships. Forest Science 30: 364-372. [on- 
line] URL: http://www.ingentaconnect.com/content/saf/fs/1984/00000030/00000002/art00015

Edwards CA (1988). Breakdown of animal, vegetable and industrial organic wastes by earthworms. In: "Earthworms in Waste and Environmental Management" (Edwards CA, Neuhauser EF eds). SPB Academic Publishing, The Hague, The Netherlands, pp. 21-31.

Edwards CA, Bohlen PJ (1996). Biology and ecology of earthworms ( $3^{\text {rd }}$ edn). Chapman and Hall, London, UK, pp. 426. [online] URL: http://books.google.com/books?id=ad4rDwD_GhsC

Erwin DC, Bartnicki-Garcia S, Tsao PH (1983). Phytophthora: its biology, taxonomy, ecology, and pathology. The American Phytopathological Society, St. Paul, MN, USA, pp. 364

Fitter AH, Garbaye J (1994). Interactions between mycorrhizal fungi and other soil organisms. Plant and Soil 159: 23-132. [online] URL: http:// link.springer.com/article/10.1007/BF00000101

Foster RC (1985). The biology of the rhizosphere. In: "Ecology and management of soilborne plant pathogens" (Parker CA, Rovira AD, Moore KJ, Wong PTW, Kollmorgen JF eds). APS Press, St. Paul, MN, USA, pp.75-79.

Gange A (1993). Translocation of mycorrhizal fungi by earthworms during early succession. Soil Biology and Biochemistry 25 (8): 1021 1026. - doi: 10.1016/0038-0717(93)90149-6

Hågvar S, Kjøndal RB (1981). Effects of artificia acid rain on the microarthropod fauna in decomposing birch leaves. Pedobiologia 22: 409-422.

Hendriksen NB (1990). Leaf-litter selection by detritivore and geophagous earthworms. Biology and Fertility of Soils 10: 17-21. [online] URL: http://link.springer.com/article/10.1007/BF0033 6119

Henrion B, Chevalier G, Martin F (1994). Typing truffle species by PCR amplification of the ribosomal DNA spacers. Mycological Research 98 37-43. - doi: 10.1016/S0953-7562(09)80333-X Ingham ER, Coleman DC, Moore JC (1989). An analysis of food-web structure and function in a shortgrass prairie, a mountain meadow, and a lodgepole pine forest. Biology and Fertility of Soils 8: 29-37. - doi: 10.1007/BF00260513

Jayasinghe BD, Parkinson D (2009). Earthworms as the vectors of actinomycetes antagonistic to litter decomposer fungi. Applied Soil Ecology 43 (1): 1-10. - doi: 10.1016/j.apsoil.2009.06.001 Judas M (1992). Gut content analysis of earthworms (Lumbricidae) in a beechwood. Soil Biology and Biochemistry 24 (12): 1413-1417. doi: 10.1016/0038-0717(92)90126-I

Kim JT, Park IH, Lee HB, Hahm YB, Yu SH (2001). Identification of Verticillium dahliae and V. albo-atrum causing wilt of tomato in Korea. Plant Pathology Journal 17: 222-226. [online] URL: http://www.dbpia.co.kr/Journal/ArticleDetail/628295

Kotter MM, Farentinos RC (1984). Formation of ponderosa pine ectomycorrhizae after inoculation with faeces of tassel-eared squirrels. Mycologia 76: 758-760. - doi: 10.2307/3793237

Kottke I, Guttenberger M, Hampp R, Oberwinkler F (1987). An in vitro method for establishing mycorrhizae on coniferous tree seedlings. Trees 1: 191-194. - doi: 10.1007/BF00193562

Laflamme G (2010). Root diseases in forest ecosystems. Canadian Journal of Plant Pathology 32 (1): 68-76. - doi: 10.1080/0706066100362 1779

Lavelle P, Bignell D, Lepage M, Wolters V, Roger P, Ineson P, Heal OW, Dhillion S (1997). Soil function in a changing world: the role of invertebrate ecosystem engineers. European Journal of Soil Biology 33: 159-193. [online] URL: http://cat.inist.fr/?aModele $=$ afficheN\&cpsidt $=23$ 74419

Lowe CN, Butt KR (2005). Culture techniques for soil dwelling earthworms: a review. Pedobiologia 49: 401-413. - doi: 10.1016/j.pedobi.2005.04.0 05

Manion PD (1981). Tree disease concepts. Prentice-Hall Inc., Englewood Cliffs, NJ, USA, pp. 399. [online] URL: http://www.cabdirect.org/abstracts/19810672031.html

Mather JG, Christensen O (1988). Surface movements of earthworms in agricultural land. Pedobiologia 32: 399-405. [online] URL: http://www. cabdirect.org/abstracts/19891932060.html

Montecchio L (2005). Damping-off of beech seedlings caused by Fusarium avenaceum in Italy. Plant Disease 89 (9): 1014-1014. - doi: 10.1094/ PD-89-1014A

Montecchio L, Mutto Accordi S (2007). Endophytic occurrence of a pathogenic strain of Fusarium reticulatum in English oak in Italy. Journal of Plant Pathology 89: 74-74. [online] URL: http://www.cabdirect.org/abstracts/20083005705 .html

Montecchio L, Causin R (1995). First report of Cylindrocarpon destructans on English walnut in Italy. Plant Disease 79 : 967-967. - doi: 10.10 94/PD-79-0967B

Moody SA, Briones MJ, Piearce TG, Dighton J (1995). Selective consumption of decomposing wheat straw by earthworms. Soil Biology and Biochemistry 27 (9): 1209-1213. - doi: 10.1016/ 0038-0717(95)00024-9

Moody SA, Piearce TG, Dighton J (1996). Fate of some fungal spores associated with wheat straw decomposition on passage through the guts of Lumbricus terrestris and Aporrectodea longa. Soil Biology and Biochemistry 28 (4-5): 533537. - doi: 10.1016/0038-0717(95)00172-7

Morris MH, Perez-Perez MA, Smith ME, Bledsoe CS (2008). Multiple species of ectomycorrhizal fungi are frequently detected on individual oak root tips in a tropical cloud forest. Mycorrhiza 18 (8): 375-383. - doi: 10.1007/s00572-008-0186-1 Ndubizu TOC (2008). Effects of earthworms, nematodes, cultivations and host plants on Verticillium wilt of peach and cherry. Annals of Applied Biology 86 (2): 153-161. - doi: 10.1111/j.17447348.1977.tb01828.x

Nelson PE, Toussoun TA, Marasas WFO (1983). Fusarium species: an illustrated manual for identification. Pennsylvania State University Press, University Park, PA, USA, pp. 193.

Nilson S, Persson O (1978). Fungi of northern Europe. 2, Gill Fungi. Penguin Nature Guides,
Penguin Books, London, UK, pp. 36. Papavizas GC, Lumsden RD (1982). Improved medium for isolation of Trichoderma spp. from soil. Plant Disease 66: 1019-1020. - doi: 10.1094 /PD-66-1019

Pečiulyte D, Dirginčiute-Volodkiene V (2009). Effect of long-term industrial pollution on microorganisms in soil of deciduous forests situated along a pollution gradient next to a fertilizer factory. 2. Abundance and diversity of soil fungi. Ekologija 55 (2): 133-141. - doi: 10.2478/v1005 5-009-0017-5

Piearce TG (1978). Gut contents of some lumbricid earthworms. Pedobiologia 18: 153-157.

Prospero S, Holdenrieder O, Rigling D (2004). Comparison of the virulence of Armillaria cepistipes and Armillaria ostoyae on four Norway spruce provenances. Forest Pathology 34 (1): 114. - doi: 10.1046/j.1437-4781.2003.00339.x Reddell P, Spain AV (1991). Earthworms as vectors of viable propagules of mycorrhizal fungi. Soil Biology and Biochemistry 23 (8): 767-774. - doi: 10.1016/0038-0717(91)90147-C

Rifai MA (1969). A revision of the genus Trichoderma. Mycol Papers 116: 1-56.

Samuels GJ, Rossman AY, Chaver P, Overton BE, Poldmaa K (2006). Hypocreales of the southeastern United States: an identification guide. CBS Biodiversity 4: 1-145.

Saravanakumar K, Kaviyarasan V (2010). Seasonal distribution of soil fungi and chemical properties of montane wet temperate forest types of Tamil Nadu. African Journal of Plant Science 4 (6): 190-196. [online] URL: http://www.academicjournals.org/article/article1380118031 Sar avanakumarandKaviyarasan.pdf

Scheu S (1987). The role of substrate feeding earthworms (Lumbricidae) for bioturbation in a beechwood soil. Oecologia 72 (2): 192-196. doi: 10.1007/BF00379266

Scheu S, Schaefer M (1988). Bottom-up control of the soil macrofauna community in a beechwood on limestone: manipulation of food resources. Ecology 79 (5): 1573-1585. - doi: 10.18 90/0012-9658(1998)079[1573:BUCOTS]2.0.CO ;2

Shankar SG, Ranganathan S, Ranjith MS, Vijayalakshmi GS (2002). Did earthworms contribute to the parasitic evolution of dermatophytes? Mycoses 45 (9-10): 399-401. - doi: 10.1046/j.14390507.2002.00772.x

Smith SE (1985). A mathematical model of vescicular-arbuscular mycorrhizal infection in roots of Trifolium subterraneum. In: "Ecology and management of soilborne plant pathogens" (Parker CA, Rovira AD, Moore KJ, Wong PTW, Kollmorgen JF eds). APS Press, St. Paul, MN, USA, pp.88-91.

Smith SE, Read DJ (2008). Mycorrhizal symbiosis. Academic Press, London, UK, pp. 800.

Subramanian CV (1982). Tropical mycology: future needs and development. Current Science 51: 321-325. [online] URL: http://repository.ias.ac. in/51719/1/1-pub.pdf

Subramanian CV (1986). The progress and status of mycology in India. Proceedings - Plant Sci- 
ences 96: 379-392. [online] URL: http://link. springer.com/article/10.1007/BF03053316

Takeda H, Ichimura T (1983). Feeding attributes of four species of collembola in a pine forest soil. Pedobiologia 25: 373-381. [online] URL: http:// cat.inist.fr/?aModele $=$ afficheN\&cpsidt $=9531818$ Tiunov AV, Scheu S (2000). Microbial biomass, biovolume and respiration in Lumbricus terrestris L. cast material of different age. Soil Biology and Biochemistry 32 (2): 265-275. - doi: 10.1016/S0038-0717(99)00165-0
Tousson TA, Bega RV, Nelson PE (1970). Root diseases and soil-borne pathogens. University of California Press, Berkeley, CA, USA, pp. 240.

Trappe JM (1988). Lessons from Alpine fungi. Mycologia 80 (1): 1. - doi: 10.2307/3807486

Vettraino AM, Barzanti GP, Bianco MC, Ragazzi A, Capretti P, Paoletti E, Luisi N, Anselmi N, Vannini A (2002). Occurrence of Phytophthora species in oak stands in Italy and their association with declining oak trees. Forest Pathology 32 (1): 19-28. - doi: 10.1046/j.1439-0329.2002. 00264.x

Visser S (1985). Role of soil invertebrates in determining the composition of soil microbial communities. In: "Ecological interactions in the soil" (Fitter AHD, Atkinson DJ, Read Usher MB eds). Blackwell Scientific Publications, Oxford, UK, pp. 297-317.

Zanella A, Tomasi M, De Siena C, Frizzera L, Jabiol B, Nicolini G (2001). Humus forestali. Centro di Ecologia Alpina Ed., Trento, Italy, pp. 320 . 